\title{
Extended negative dietary cation-anion difference feeding does not negatively affect postpartum performance of multiparous dairy cows
}

\author{
W. Weich, ${ }^{*}$ E. Block, $†$ and N. B. Litherland ${ }^{* 1}$ \\ *Department of Animal Science, University of Minnesota, St. Paul 55108 \\ †Church \& Dwight Co. Inc., Arm \& Hammer Animal Nutrition, Princeton, NJ 08543
}

\begin{abstract}
Low postpartum blood calcium remains one of the largest constraints to postpartum feed intake, milk yield, and energy balance in transitioning dairy cows. Supplemental dietary anions decrease the dietary cation-anion difference (DCAD) and reduce the risk for postpartum hypocalcemia. Prepartum management strategies aiming to minimize social stress and diet changes have resulted in a need to explore the effects of extended exposure to a negative DCAD ( $>21 \mathrm{~d})$ diet. Holstein and Holstein-cross dairy cows $(\mathrm{n}=60)$ were assigned to 1 of 3 treatments $42 \mathrm{~d}$ before expected calving to evaluate effects of supplying anions for 21 or $42 \mathrm{~d}$ during the dry period on energy status, postpartum production, and Ca homeostasis. Treatments included (1) a control $\operatorname{diet}(\mathrm{CON} ; \mathrm{DCAD}=12 \mathrm{mEq} / 100 \mathrm{~g}$ of $\mathrm{DM}),(2)$ a $21-\mathrm{d}$ negative DCAD diet (21-ND; DCAD $=12$ and -16 $\mathrm{mEq} / 100 \mathrm{~g}$ of $\mathrm{DM}$ ), and (3) a 42-d negative DCAD diet $(42-\mathrm{ND} ; \mathrm{DCAD}=-16 \mathrm{mEq} / 100 \mathrm{~g}$ of $\mathrm{DM})$. Cows fed CON were fed positive DCAD prepartum for $42 \mathrm{~d}$. Cows fed 21-ND received the positive DCAD $(12 \mathrm{mEq} / 100 \mathrm{~g}$ of $\mathrm{DM}$ ) diet for the first $21 \mathrm{~d}$ of the dry period and the anionic diet $(-16 \mathrm{mEq} / 100 \mathrm{~g}$ of $\mathrm{DM})$ from d 22 until calving. Cows fed 42-ND received the anionic diet for the entire dry period. Control and anionic diets were formulated by using 2 isonitrogenous protein mixes: (1) 97.5\% soybean meal and (2) 52.8\% BioChlor (Church \& Dwight Co. Inc.), 45.8\% soybean meal. Supplementing anions induced a mild metabolic acidosis, reducing urine $\mathrm{pH}$ for $21-\mathrm{ND}$ and $42-\mathrm{ND}$ compared with CON. Prepartum DMI was not different among treatments. Postpartum DMI was higher for 21-ND compared with CON (20.8 vs. $18.1 \pm 1.1 \mathrm{~kg} / \mathrm{d}$ ), and 42-ND had similar DMI compared with 21-ND. During the first $56 \mathrm{~d}$ of lactation 21-ND had greater average milk production compared with CON (44.8 vs. $39.2 \pm 2.1 \mathrm{~kg} / \mathrm{d}$ ). Average milk production by $42-\mathrm{ND}$ was similar to $21-\mathrm{ND}$. Postpartum total blood Ca concentration was greater
\end{abstract}

Received December 13, 2012.

Accepted May 20, 2013.

${ }^{1}$ Corresponding author: lithe003@umn.edu for 42-ND. Cows fed anionic diets prepartum tended to have lower lipid accumulation in the liver after calving compared with CON. These data suggest low-DCAD diets fed for 21 or $42 \mathrm{~d}$ during the dry period can have positive effects on postpartum DMI, Ca homeostasis, and milk production.

Key words: dietary cation-anion difference, hypocalcemia, transition dairy cow

\section{INTRODUCTION}

Low postpartum blood calcium continues to affect upwards of $10 \%$ of dairy cows clinically (milk fever) and $50 \%$ subclinically (hypocalcemia), depending on cow age and number of lactations (Reinhardt et al., 2011). According to the NAHMS (2007) survey, $26.7 \%$ of producers supplement anions to decrease the DCAD of the prepartum diet to aid against hypocalcemia $(<8$ $\mathrm{mg} / \mathrm{dL}$ total blood Ca; DeGaris and Lean, 2008). Supplementation of anions in the form of anionic salts has often resulted in reduced DMI during the prepartum period (Gaynor et al., 1989; Leclerc and Block, 1989; Oetzel and Barmore, 1993; Joyce et al., 1997; Vagnoni and Oetzel, 1998; Moore et al., 2000). To avoid using anionic products, or to decrease the extent of anionic supplementation needed to lower DCAD in the prepartum diet, a large percentage of producers (46.9\%) are selecting low-potassium forages as an alternative method to prevent hypocalcemia (NAHMS, 2007). Few studies (Moore et al., 2000; Siciliano-Jones et al., 2008; Ramos-Nieves et al., 2009) assess the need for anionic supplementation when feeding a low-cation prepartum diet.

Additionally, producers have expressed interest in grouping cohorts of dry cows with similar calving dates in the same pen to achieve the all-in, all-out strategy. Benefits of this strategy are discussed by Nordlund et al. (2006) and Nordlund (2009), and include decreased social stress due to fewer additions and removals of cows within prefresh pens. This strategy can encourage consistent DMI during the prepartum period by limiting re-establishments of hierarchies, competition for feed, and feed bunk displacements (Hasegawa et al., 1997; von Keyserlingk et al., 2008). 
In an effort to reduce stresses associated with cow movement and to reduce feeding management issues, 1 dry cow diet could be fed to cows grouped by these recommendations; however, limited research is available on extended negative DCAD feeding. Current feeding strategies for supplementing anions during the prepartum period are largely based on results reported by Oetzel et al. (1988), who discovered improvements in postpartum blood $\mathrm{Ca}$ and decreased hypocalcemia could be made by the inclusion of dietary anions for 21 d prepartum. However, research (Block, 1984) suggests extended negative DCAD may be more beneficial to transition cows to improve $\mathrm{Ca}$ homeostasis through calving and increase postpartum performance.

The objectives of this study were to re-evaluate the benefits of reduced DCAD in prepartum diets inherently low in cations due to selection of low-potassium forages and, second, to explore the effects of extended negative DCAD feeding on Ca homeostasis, DMI, and, thus, energy status and postpartum milk yield. We hypothesized that feeding a negative DCAD $21 \mathrm{~d}$ prepartum would result in greater postpartum performance compared with control and, second, negative DCAD for 21 and $42 \mathrm{~d}$ would result in similar performance.

\section{MATERIALS AND METHODS}

\section{Treatments}

Ration-balancing software, CPM Dairy (Version 3.0.8; Cornell University, Ithaca, NY; University of Pennsylvania, Kennett Square, PA; and William H. Miner Agricultural Research Institute, Chazy, NY), was used to formulate diets supplying adequate $\mathrm{NE}_{\mathrm{L}}$ and metabolizable protein for 650-kg dry cows $280 \mathrm{~d}$ in gestation. Positive and negative DCAD diets were produced by altering the ingredient composition (Table 1) of the prepartum protein mixes. Diet nutrient profiles are described in Table 2. Crude protein concentrations of the dry cow diets were higher than anticipated. Additional amounts of anions were necessary to maintain a urine $\mathrm{pH}$ in the optimal range identified for $\mathrm{Ca}$ homeostasis (Goff, 2008). Ultimately, this led to an increase in dry cow diet $\mathrm{CP}$ amounts, as the DCADlowering feed additive was blended with the protein source. Crude protein concentration of the control diet were adjusted accordingly to keep prepartum diets isonitrogenous. Dietary cation-anion difference (DM basis) of the prepartum diets was determined through weekly collection of individual ingredients, which were composited by ingredient by month and analyzed for mineral content (AOAC International, 1995) in addition to nutrient analysis. Nutrient and mineral profiles of each ingredient were entered into CPM Dairy to cal- culate DCAD for each treatment on a monthly basis. Treatments included (1) a 42-d control diet (CON; DCAD $12 \mathrm{mEq} / 100 \mathrm{~g}$ of DM), (2) a 21-d BioChlor diet (21-ND; Church \& Dwight Co. Inc.; DCAD 12 and $-16 \mathrm{mEq} / 100 \mathrm{~g}$ of $\mathrm{DM}$ ), and (3) a 42 -d BioChlor diet (42-ND; Church \& Dwight Co. Inc.; DCAD -16 $\mathrm{mEq} / 100 \mathrm{~g}$ of $\mathrm{DM})$. The control group received the positive DCAD from d -42 until parturition, with cows on 21-ND receiving the positive DCAD (CON) from $d$ -42 through -22 and the negative DCAD from $\mathrm{d}-21$ to parturition. The $42-\mathrm{ND}$ treatment group received the negative DCAD for the entire 42-d dry period.

\section{Assignment to Treatments}

On d -42 before expected calving date, 60 multiparous Holstein and Holstein-cross dairy cows were placed on 1 of 3 prepartum treatments. Prior to the start of the trial, treatment groups were balanced (Table 3) for previous $305 \mathrm{~d}$ mature-equivalent milk yield (11,343.0 $\pm 1,754.0 \mathrm{~kg}$; mean $\pm \mathrm{SD}$ ), BW at dry-off (643.5 \pm $96.7 \mathrm{~kg})$, BCS at dry-off $(3.3 \pm 0.3$ points $)$, and parity $(2.0 \pm 1.2$ lactations). Days dry were similar $(P=$ $0.89)$ among treatments $(44.9 \pm 7.9 \mathrm{~d})$. One cow from both CON and 21-ND were removed due to unidentified health complications 1 wk postpartum. Three cows from 21-ND prematurely calved ( $>3$ wk early), resulting in their removal from the analysis. Dystocia associated with twinning resulted in loss of 1 cow from CON. A cow from 21-ND was removed due to development of an abomasal ulcer, and 1 cow from both 21-ND and 42-ND were removed due to developed lameness (Table 3). All prepartum and postpartum data from removed cows were absent from analysis.

\section{Animal Housing and Management}

The experimental protocol was reviewed and approved by the University of Minnesota Institutional Animal Care and Use Committee (IACUC\# 1008A87152). Cows were housed in a tiestall barn on rubber mattresses bedded daily with sawdust. Cows were fed in individual feed bunks once daily prepartum at $1100 \mathrm{~h}$. After calving all cows received a common lactation diet (Tables 1 and 2) and were fed twice daily at 0600 and $1200 \mathrm{~h}$. Feed was offered at approximately 10 and $90 \%$ of the daily allocation for the morning and afternoon feeding, respectively. Cows were milked twice daily at 0200 and $1400 \mathrm{~h}$.

\section{Sample Collection and Preparation}

Feed Collection and Analysis. Individual feed ingredients comprising the dry cow diets and lactation diet 
Table 1. Ingredient composition for prepartum and postpartum diets fed to multiparous dairy cows from d 42 prepartum through d 56 postpartum

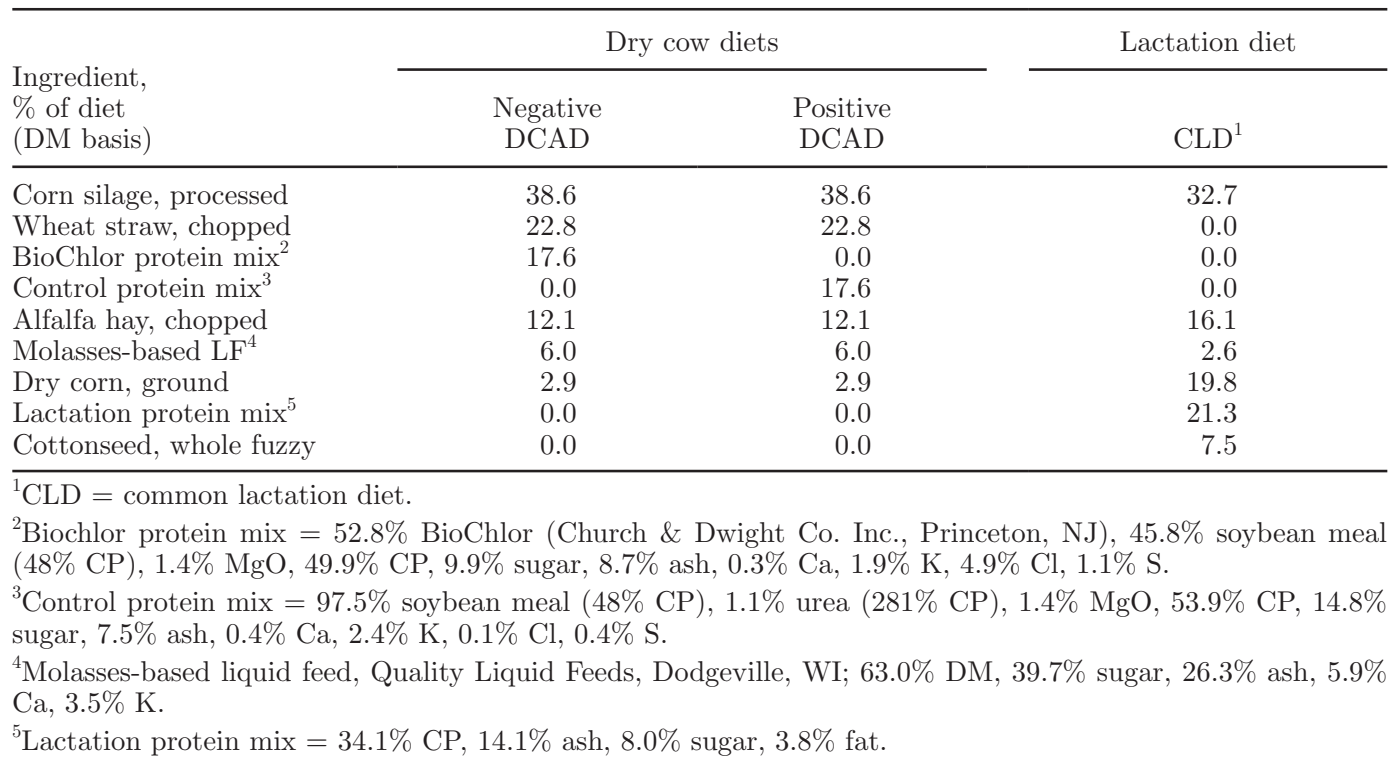

(Table 2) were collected weekly, composited by month, and analyzed in a commercial laboratory (Package E, Dairyland Labs Inc., St. Cloud, MN) using wet chemistry procedures. Compositing weekly samples from each month was accomplished by commingling and mixing all samples from the month, followed by quartering the composited feed into 4 equal sections. One quarter was saved and frozen, whereas another quarter was used for nutrient analysis. Mineral content of ingredients, excluding chloride, was determined through inductively coupled plasma spectroscopy (AOAC International, 1995). Ingredient chloride content was determined using a direct reading chloride analyzer (Corning 926, Corning Inc., Corning, NY).

DMI, Nutrient Intake, Milk Production, and Milk Components. Daily DMI was calculated $42 \mathrm{~d}$ prepartum through $56 \mathrm{~d}$ postpartum. Individual daily as-fed feeding amounts and feed refusal amounts were collected using a Super Data Ranger feed cart (American Calan, Northwood, NH). Dry matter of forages, grains, protein mixtures, prepartum treatment diets, and common lactation diet were determined weekly by drying at $60^{\circ} \mathrm{C}$ until reaching a static weight. Individual as-fed feed amounts and refused feed amounts were multiplied by corresponding weekly DM of the TMR to correct for DM. Refused DM was subtracted from offered DM to obtain DMI. Amounts of ingredients added to the TMR were adjusted weekly based on changes in ingredient DM. Energy balance (EB; Mcal/d) was calculated using equations (NRC, 2001) for each cow on a weekly basis. Net energy intake $\left(\mathrm{NE}_{\mathrm{I}}\right)$ was determined by multiplying DMI by the calculated mean $\mathrm{NE}_{\mathrm{L}}$ density of the diet.
The $\mathrm{NE}_{\mathrm{L}}$ value of each individual feed (Dairyland Labs) was used to calculate the mean $\mathrm{NE}_{\mathrm{L}}$ content of the diet. Net energy required for maintenance was calculated as $\mathrm{BW}^{0.75} \times 0.08$. Net energy requirements for pregnancy $\left(\mathrm{NE}_{\mathrm{P}}\right)$ were calculated as $[(0.00318 \times$ day of gestation $0.0352) \times($ calf birth weight/45)]/0.218. Milk net energy requirements $\left(\mathrm{NE}_{\mathrm{L}}\right)$ were calculated as $(0.0929 \times$ fat $\%$ $=0.0563 \times$ protein $\%+0.0395 \times$ lactose $\%) \times$ milk. The following equation was used to calculate prepartum energy balance was $\mathrm{NE}_{\mathrm{I}}-\left(\mathrm{NE}_{\mathrm{M}}+\mathrm{NE}_{\mathrm{P}}\right)$. The equation used to calculate postpartum energy balance was $\mathrm{NE}_{\mathrm{I}}$ - $\left(\mathrm{NE}_{\mathrm{M}}+\mathrm{NE}_{\mathrm{L}}\right)$. Daily milk weights were recorded individually through 56 DIM. Milk samples were collected from individual cows weekly on wk 1 through 4 from consecutive a.m. and p.m. milkings and were preserved (800 Broad Spectrum Microtabs II; D and F Control Systems Inc., San Ramon, CA) until analysis using midinfrared procedures (AOAC International, 1995) at DHIA (Zumbrota, MN) for fat, protein, lactose, SCC, and MUN.

$\boldsymbol{B} \boldsymbol{W}$ and $\boldsymbol{B C S}$. Body weight and BCS were recorded once weekly for wk -6 through 4 relative to calving. Body condition score was evaluated using a 1- to 5-scale with 0.25-unit increments (Ferguson et al., 1994). Three trained scorers assigned BCS values which were then averaged into 1 score per cow per week.

Blood Collection, Processing, and Analysis. Blood was collected from the coccygeal vein or artery into evacuated serum (serum separator, Becton Dickinson Vacutainer Systems, Franklin Lakes, NJ) or plasma tubes (trace element, Becton Dickinson Vacutainer Systems) before feeding at approximately $0900 \mathrm{~h}$. Se- 
Table 2. Nutrient composition for prepartum and postpartum diets (DM basis) fed to multiparous dairy cows from d 42 prepartum through d 56 postpartum (CPM Dairy version 3.0.8; Cornell University, Ithaca, NY; University of Pennsylvania, Kennett Square, PA; and William H. Miner Agricultural Research Institute, Chazy, NY) ${ }^{1}$

\begin{tabular}{|c|c|c|c|}
\hline \multirow[b]{2}{*}{ Item } & \multicolumn{2}{|c|}{ Dry cow diet } & \multirow{2}{*}{$\begin{array}{c}\text { Lactation diet } \\
\mathrm{CLD}^{2}\end{array}$} \\
\hline & $\begin{array}{l}\text { Negative } \\
\text { DCAD }\end{array}$ & $\begin{array}{l}\text { Positive } \\
\text { DCAD }\end{array}$ & \\
\hline $\mathrm{DM}, \%$ & 61.13 & 61.95 & 63.96 \\
\hline Forage, \% & 74.09 & 74.09 & 50.83 \\
\hline $\mathrm{CP}, \%$ & 16.65 & 17.33 & 16.60 \\
\hline RUP, $\%$ of $\mathrm{CP}$ & 21.38 & 19.70 & 38.89 \\
\hline $\mathrm{RDP}, \%$ of $\mathrm{CP}$ & 78.62 & 80.30 & 61.11 \\
\hline RDP, \% & 13.06 & 13.91 & 10.14 \\
\hline Soluble protein, ${ }^{3} \%$ of $\mathrm{CP}$ & 55.57 & 47.83 & 30.94 \\
\hline $\mathrm{NE}_{\mathrm{L}}, \mathrm{Mcal} / \mathrm{kg}$ & 1.47 & 1.47 & 1.66 \\
\hline $\mathrm{ADF}, \%$ & 28.32 & 28.10 & 22.24 \\
\hline NDF, \% & 42.54 & 41.35 & 31.56 \\
\hline Physically effective NDF, \% & 37.25 & 37.72 & 23.95 \\
\hline Lignin, \% & 4.51 & 4.36 & 4.48 \\
\hline $\mathrm{NFC},{ }^{4} \%$ & 31.30 & 32.00 & 42.84 \\
\hline Sugar, \% & 6.11 & 6.82 & 5.57 \\
\hline Starch, \% & 12.25 & 11.03 & 26.12 \\
\hline Soluble fiber, $\%$ & 10.13 & 11.34 & 8.68 \\
\hline Total ether extract, $\%$ & 2.00 & 1.83 & 3.97 \\
\hline Ash, \% & 9.01 & 8.80 & 7.42 \\
\hline $\mathrm{Ca}, \%$ & 0.80 & 0.82 & 0.80 \\
\hline $\mathrm{P}, \%$ & 0.41 & 0.40 & 0.47 \\
\hline $\mathrm{Mg}, \%$ & 0.39 & 0.39 & 0.32 \\
\hline $\mathrm{K}, \%$ & 1.42 & 1.51 & 1.43 \\
\hline $\mathrm{S}, \%$ & 0.40 & 0.29 & 0.27 \\
\hline $\mathrm{Na}, \%$ & 0.18 & 0.07 & 0.46 \\
\hline Chlorine, $\%$ & 1.23 & 0.42 & 0.49 \\
\hline Vitamin D, IU/kg & $2,118.64$ & $2,118.64$ & 849.42 \\
\hline Vitamin E, IU/kg & 105.98 & 105.98 & 42.48 \\
\hline $\mathrm{DCAD} 1,{ }^{5} \mathrm{mEq} / 100 \mathrm{~g}$ & -15.79 & 12.34 & 25.68 \\
\hline DCAD $2,{ }^{6} \mathrm{mEq} / 100 \mathrm{~g}$ & -6.94 & 18.85 & 28.50 \\
\hline
\end{tabular}

${ }^{1}$ Feedstuffs composing diets were collected weekly, composited by month, and analyzed by wet chemistry to determine actual diet nutrient compositions.

${ }^{2}$ Common lactation diet.

${ }^{3}$ Soluble protein $(\%)=\mathrm{CP}(\%)-$ insoluble protein $(\%)$.

${ }^{4} \mathrm{NFC}=100-[(\mathrm{NDF}-$ neutral detergent insoluble $\mathrm{CP})+\mathrm{CP}+$ ash + fat $\left.)\right]$.

${ }^{5} \mathrm{DCAD} 1=[(\mathrm{Na}+\mathrm{K})-(\mathrm{Cl}+\mathrm{S})]$.

${ }^{6} \mathrm{DCAD} 2=[(\mathrm{Na}+\mathrm{K}+0.38 \mathrm{Ca}+0.30 \mathrm{Mg})-(\mathrm{Cl}+0.6 \mathrm{~S}+0.5 \mathrm{P})]$.

rum was collected $-28,-21,-14,-7,-3,-1,1,3,7$, 14 , and $21 \mathrm{~d}$ relative to calving. Blood collection tubes were centrifuged at $1,300 \times g$ for $20 \mathrm{~min}$ at $4^{\circ} \mathrm{C}$, and the supernatant was removed by disposable pipette and immediately frozen at $-20^{\circ} \mathrm{C}$ until analysis for NEFA [HR Series NEFA - HR(2), Wako Chemicals USA Inc., Richmond, VA], BHBA (Precision Xtra Meter, Abbott Laboratories Inc., Abbott Park, IL) and ionized Ca (iCa; Michigan State Diagnostic Laboratory, East Lansing, MI). Serum from each sample day was used to determine pre- and postpartum NEFA concentrations, whereas BHBA was only analyzed on postpartum sample days. Serum samples from $\mathrm{d}-3,-1,1,3$, and 7 were analyzed for iCa. Plasma was collected -72 , $-24,12,24$, and $72 \mathrm{~h}$ relative to calving and processed similar to serum. Plasma was analyzed by inductively coupled plasma spectroscopy (AOAC International,
1995) for total Ca (tCa; University of Minnesota Soils Laboratory, St. Paul, MN).

Liver Biopsy, Total Lipids Assay, Glycogen Assay, and Triacylglycerol Assay. Liver biopsies were collected $-14,7$, and 14 d relative to calving at approximately $0700 \mathrm{~h}$ via puncture biopsy (Hughes, 1962; Veenhuizen et al., 1991). Before biopsy, local anesthesia was infiltrated in the intercostal space posterior to the tenth rib followed by aseptic preparation of the surgical site. Liver cores were immediately flash frozen in liquid nitrogen, transferred to a $-80^{\circ} \mathrm{C}$ storage freezer, where they awaited analysis for percent total lipids (TL; Hara and Radin, 1978), percent triacylglycerol (TAG; Fletcher, 1968; Foster and Dunn, 1973), and percent glycogen (GLC; Lo et al., 1970).

Urine Sampling and Analysis. Urine samples were collected individually by manual stimulation of the 
Table 3. Least squares means for finalized treatment assignments for multiparous cows $7 \mathrm{~d}$ before assignment to prepartum treatment with positive DCAD (CON) for $42 \mathrm{~d}$ prepartum or negative DCAD (21-ND or 42-ND) for 21 or $42 \mathrm{~d}$ prepartum

\begin{tabular}{|c|c|c|c|c|}
\hline \multirow[b]{2}{*}{ Item } & \multicolumn{3}{|c|}{ Treatment $^{1}$} & \multirow[b]{2}{*}{$P$-value } \\
\hline & $\mathrm{CON}$ & $21-\mathrm{ND}$ & $42-\mathrm{ND}$ & \\
\hline Cows, n & 19 & 14 & 20 & - \\
\hline Holstein, $\mathrm{n}$ & 8 & 4 & 10 & - \\
\hline Holstein-cross, n & 11 & 10 & 10 & - \\
\hline Previous MT-E, ${ }^{2} \mathrm{~kg}$ & $11,695.3 \pm 409.5$ & $11,574.4 \pm 472.2$ & $11,119.0 \pm 385.0$ & 0.57 \\
\hline $\mathrm{BCS}^{3}$ & $3.3 \pm 0.1$ & $3.1 \pm 0.1$ & $3.3 \pm 0.1$ & 0.25 \\
\hline $\mathrm{BW}, \mathrm{kg}$ & $661.6 \pm 23.4$ & $622.2 \pm 28.0$ & $650.5 \pm 22.3$ & 0.54 \\
\hline Parity $^{4}$ & $2.0 \pm 0.3$ & $1.9 \pm 0.3$ & $2.1 \pm 0.3$ & 0.84 \\
\hline Treatment length, ${ }^{5} \mathrm{~d}$ & $44.9 \pm 2.1$ & $44.7 \pm 2.3$ & $43.7 \pm 1.9$ & 0.89 \\
\hline
\end{tabular}

${ }^{1}$ Cows assigned to CON received a prepartum diet with a DCAD value of $12 \mathrm{mEq} / 100 \mathrm{~g}$ of DM; $21-\mathrm{ND}$ received a prepartum diet with a DCAD value of $-16 \mathrm{mEq} / 100 \mathrm{~g}$ of $\mathrm{DM}$ for $21 \mathrm{~d}$ prepartum; and those assigned to 42 ND received a prepartum diet with a DCAD value of $-16 \mathrm{mEq} / 100 \mathrm{~g}$ for $42 \mathrm{~d}$ prepartum.

${ }^{2}$ Previous MT-E: 305-d mature equivalent milk yield.

${ }^{3} \mathrm{BCS}=1-5$ scale, 0.25 unit increments.

${ }^{4}$ Number of previous lactations.

${ }^{5}$ Days dry.

vulva on wk $-5,-3,-2$, and -1 before calving. Urine was collected at approximately $1100 \mathrm{~h}$ and analysis was completed within $1 \mathrm{~h}$ of sample collection. A portable $\mathrm{pH}$ meter (Corning 345, Corning Inc.) was calibrated weekly and used to determine urine $\mathrm{pH}$.

Health Events. Cows were observed daily from d -42 before calving through 56 DIM. Rectal body temperature was monitored for $7 \mathrm{~d}$ following calving and for $3 \mathrm{~d}$ following each liver biopsy. Adverse health events were recorded, with unhealthy cows treated by the barn staff or attending veterinarian. Cows identified with ketosis by farm management (Ketostix, Bayer Corp., Elkhart, IN) were drenched with propylene glycol $(0.24 \mathrm{~L})$ in $19 \mathrm{~L}$ of water. Cows succumbing to clinical milk fever were intravenously administered 500 $\mathrm{mL}$ of aqueous solution containing $75.0 \mathrm{~g}$ of dextrose, $10.8 \mathrm{~g}$ of $\mathrm{Ca}$ (as Ca borogluconate), $8.0 \mathrm{~g}$ of $\mathrm{K}, 2.5 \mathrm{~g}$ of $\mathrm{P}$, and $1.6 \mathrm{~g}$ of $\mathrm{Mg}$ (calcium-magnesium-phosphorouspotassium-dextrose Solution, Vedco, St. Joseph, MO). Treatment was repeated hourly if symptoms did not reverse. Spectramast LC (Pfizer Animal Health, New York, NY), ToDAY (Boehringer Ingelheim Vetmedica Inc., St. Joseph, MO), and Pirsue (Pfizer Animal Health) were used to treat cases of mastitis. Metritis was treated with Excenel (Pfizer Animal Health).

Calf and Colostrum Data. Calving ease scores were recorded by trained technicians applying the following criterion: $1=$ unassisted calving; $2=$ calving requiring slight assistance; $3=$ calving requiring moderate assistance; $4=$ calving requiring significant help; and $5=$ mechanically assisted pull. Calves were weighed within $24 \mathrm{~h}$ after birth. Colostrum weights were recorded as the first a.m. or p.m. milking weight after calving.

\section{Statistical Analysis}

Statistical analysis was completed using SAS (SAS Institute, 1999). Data were analyzed as a completely randomized design. Data with multiple measurements over time were processed using the REPEATED statement in the MIXED procedure and analyzed using preplanned orthogonal contrasts (CON vs. 21-ND; 21-ND vs. $42-\mathrm{ND})$ to identify significant differences between treatments. The model included treatment, time, treatment by time, and breed. Previous 305-d mature milk yield equivalent was used as a covariate in the model for prepartum variables, such as DMI, EB, and urine $\mathrm{pH}$. Data were analyzed using compound symmetry and auto-regressive order 1 for covariance structures. The covariance structure that resulted in the Akaike's information criterion closest to zero was used (Littell et al., 1996). Data not analyzed over time were subjected to ANOVA by using the MIXED procedure of SAS (Littell et al., 1996). Least squares means for treatment, week, and treatment $\times$ week interactions were separated using the PDIFF statement. Prepartum and postpartum data sets were analyzed separately. Significant differences were declared at $P<0.05$ and trends are discussed when $P>0.05 \leq 0.10$.

\section{RESULTS}

\section{Urine $\mathrm{pH}$}

As designed, prepartum urine $\mathrm{pH}$ of $21-\mathrm{ND}$ and $42-$ ND were lower $(P<0.01)$ than CON (Figure 1) while being fed the anionic diet. Urine $\mathrm{pH}$ for $42-\mathrm{ND}$ averaged $6.6 \pm 0.1$, whereas $\mathrm{CON}$ averaged $8.2 \pm 0.1$ during the dry period. Urine $\mathrm{pH}$ for $21-\mathrm{ND}$ averaged 6.9 during 


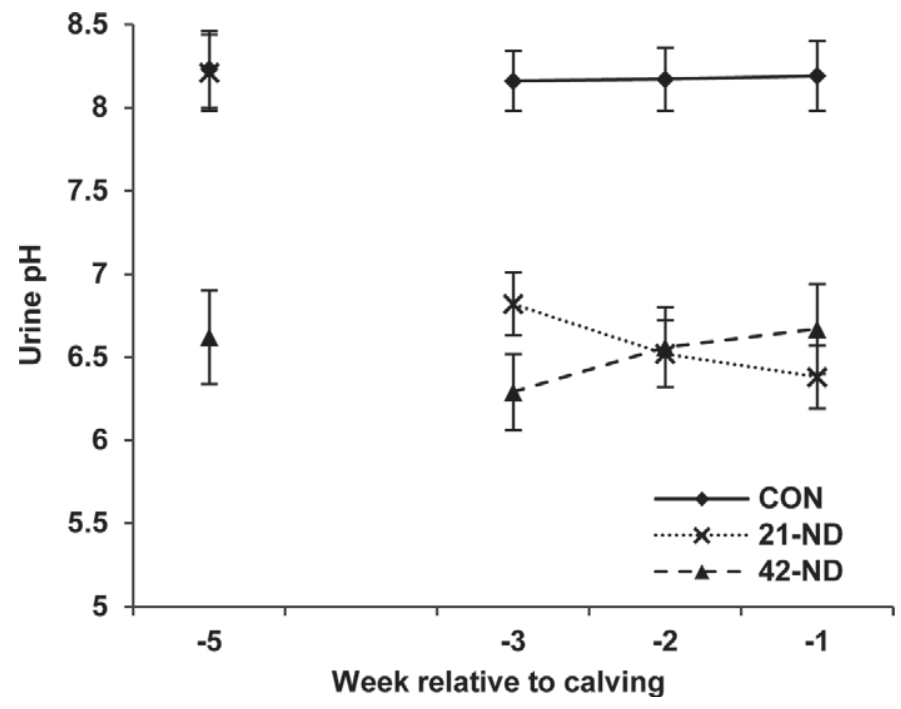

Figure 1. Prepartum urine $\mathrm{pH}$ from multiparous cows fed a control $(\mathrm{DCAD}=12 \mathrm{mEq} / 100 \mathrm{~g}$ of $\mathrm{DM}) \operatorname{diet}(\mathrm{CON})$ for $42 \mathrm{~d}$ prepartum or negative DCAD (DCAD $=-16 \mathrm{mEq} / 100 \mathrm{~g}$ of DM) diet for 21 or $42 \mathrm{~d}$ prepartum (21-ND or 42-ND). Values are LSM and error bars are SE; $\mathrm{n}=19,14$, and 20 for $\mathrm{CON}, 21-\mathrm{ND}$, and $42-\mathrm{ND}$, respectively. Urine $\mathrm{pH}$ averaged 8.2, 7.0, and $6.5 \pm 0.2$ for CON, 21-ND, and 42-ND, respectively. Treatment contrasts resulted in $P$-values of $<0.01$ and 0.03 for CON vs. $21-\mathrm{ND}$ and $21-\mathrm{ND}$ vs. $42-\mathrm{ND}$, respectively.

the dry period and was 8.2 when sampled at wk -5 , decreasing to 6.5 while receiving the negative DCAD for wk -3 through -1 .

\section{Blood Ca}

Diets had no effect on blood Ca concentrations during the prepartum period (data not shown). Postpartum iCa was not different for 21-ND compared with CON $(P=0.54)$ or $42-\mathrm{ND}(P=0.88)$, and averaged 4.64 , 4.69 , and $4.71 \pm 0.01 \mathrm{mg} / \mathrm{dL}$ for CON, 21-ND, and 42$\mathrm{ND}$, respectively. All treatments restored blood iCa at similar rates postpartum, increasing from $4.5 \mathrm{mg} / \mathrm{dL}$ at $1 \mathrm{~d}$ postpartum to $4.9 \mathrm{mg} / \mathrm{dL}$ at d 7 (treatment $\times$ day; $P=0.54)$. Cows fed the anionic diet for $21 \mathrm{~d}$ prepartum had similar postpartum tCa $(P=0.53)$ compared with CON. Cows receiving anionic supplementation for $42 \mathrm{~d}$ prepartum tended to have greater $(P=0.06)$ tCa than 21-ND (Figure 2). Concentrations of tCa remained low through $24 \mathrm{~h}$ postpartum, but increases in tCa were measured within $72 \mathrm{~h}$ postpartum, resulting in a significant time effect (hour; $P=0.001$ ).

\section{$D M I$ and $E B$}

Prepartum DMI means were unaffected by supplementation of anions for 21 or $42 \mathrm{~d}$ (Table 4), however, $21-N D$ tended $(P<0.10)$ to have greater DMI during wk -6 compared with 42-ND and wk -5 compared with CON. Dry matter intake increased after calving

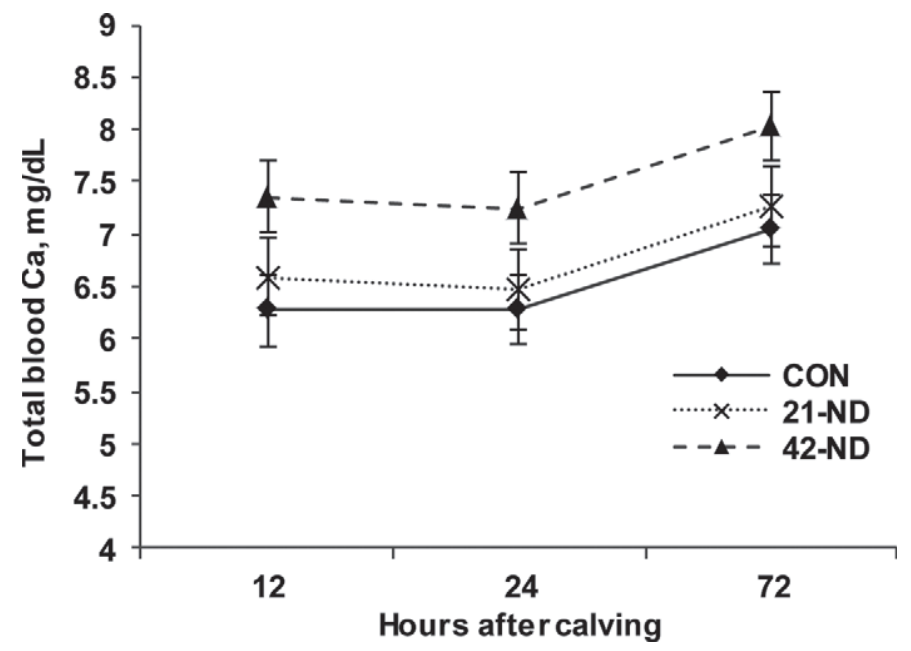

Figure 2. Postpartum total blood Ca from multiparous cows fed a control $(\mathrm{DCAD}=12 \mathrm{mEq} / 100 \mathrm{~g}$ of $\mathrm{DM}) \operatorname{diet}(\mathrm{CON})$ for $42 \mathrm{~d}$ prepartum or negative DCAD (DCAD $=-16 \mathrm{mEq} / 100 \mathrm{~g}$ of DM) diet for 21 or $42 \mathrm{~d}$ prepartum (21-ND or 42-ND). Values are LSM and error bars are SE; $\mathrm{n}=19,14$, and 20 for CON, 21-ND, and 42-ND, respectively. Postpartum total blood Ca averaged $6.5,6.8$, and $7.5 \mathrm{mg} / \mathrm{dL}$ for CON, 21-ND, and 42-ND, respectively. Treatment contrasts resulted in $P$-values of 0.53 and 0.06 for CON vs. $21-\mathrm{ND}$ and $21-\mathrm{ND}$ vs. $42-\mathrm{ND}$, respectively.

(week; $P<0.01)$ and was greater $(P=0.05)$ for 21 ND compared with CON (Figure 3). No difference in postpartum DMI was observed between cows fed negative DCAD for 21 or $42 \mathrm{~d}(P=0.38)$. All treatments followed similar increases in postpartum DMI from wk 1 through 4.

Prepartum EB was not different among treatments and averaged 5.5, 5.6, and $3.9 \pm 1.4 \mathrm{Mcal} / \mathrm{d}$ for CON, 21-ND, and 42-ND, respectively (Table 4). Due to the decrease in DMI as calving approached, prepartum EB declined from $5.5 \mathrm{Mcal} / \mathrm{d}$ in wk -2 to $3.4 \mathrm{Mcal} / \mathrm{d}$ (week; $P<0.001)$ during the wk before calving. Postpartum EB was lowest on wk $1(-9.2 \mathrm{Mcal} / \mathrm{d})$, increasing to $-5.9 \mathrm{Mcal} / \mathrm{d}$ by wk 4 postpartum, but was unaffected by prepartum treatment (Table 5 ).

Prepartum and postpartum means for BW were similar (treatment; $P=0.78$ and $P=0.91$ ) among treatments (Table 4). Cows from all treatments lost weight at equal rates after calving (treatment $\times$ week; $P=0.89$ ). Postpartum weight loss through 28 DIM was not different among treatments, although postpartum weight loss was greatest in 42-ND, resulting in 4.0 and $4.3 \mathrm{~kg}$ greater losses than CON and 21-ND, respectively. Prepartum BCS was higher $(P=0.04)$ for $\mathrm{CON}$ and $42-\mathrm{ND}(P=0.06)$ compared with $21-\mathrm{ND}$, and averaged $3.3,3.1$, and $3.3 \pm 0.1$ for CON, 21-ND, and 42-ND, respectively. Differences in prepartum BCS were maintained through 4 wk postpartum and led to CON and 42-ND having greater BCS than 21-ND (Table 4). 
Table 4. Least squares means of pre- and postpartum DMI, energy balance, BW, BCS, and prepartum urine $\mathrm{pH}$ from multiparous cows fed prepartum diets with positive DCAD (CON) for $42 \mathrm{~d}$ prepartum or negative DCAD (21-ND or $42-\mathrm{ND})$ for 21 or $42 \mathrm{~d}$ prepartum

\begin{tabular}{|c|c|c|c|c|c|}
\hline \multirow[b]{2}{*}{ Item } & \multicolumn{3}{|c|}{ Treatment $^{1}$} & \multicolumn{2}{|c|}{$P$-value ${ }^{2}$} \\
\hline & $\mathrm{CON}$ & $21-\mathrm{ND}$ & $42-\mathrm{ND}$ & $\mathrm{C} 1$ & $\mathrm{C} 2$ \\
\hline \multicolumn{6}{|l|}{ Prepartum } \\
\hline $\mathrm{DMI},{ }^{3} \mathrm{~kg} / \mathrm{d}$ & $13.6 \pm 0.7$ & $14.4 \pm 0.8$ & $12.9 \pm 0.6$ & 0.48 & 0.17 \\
\hline $\mathrm{DMI}^{3} \%$ of BW & $2.0 \pm 0.1$ & $2.0 \pm 0.1$ & $1.8 \pm 0.1$ & 0.77 & 0.30 \\
\hline $\mathrm{EB},{ }^{4,5} \mathrm{Mcal} / \mathrm{d}$ & $5.5 \pm 1.1$ & $5.6 \pm 1.4$ & $3.9 \pm 1.1$ & 0.96 & 0.34 \\
\hline $\mathrm{EB},{ }^{4,6} \%$ Req. & $137.0 \pm 8.2$ & $137.6 \pm 9.7$ & $127.9 \pm 7.9$ & 0.96 & 0.44 \\
\hline $\mathrm{BW},{ }^{7} \mathrm{~kg}$ & $710.1 \pm 22.8$ & $685.4 \pm 26.9$ & $701.2 \pm 21.9$ & 0.48 & 0.65 \\
\hline $\mathrm{BCS}^{7,8}$ & $3.3 \pm 0.1$ & $3.1 \pm 0.1$ & $3.3 \pm 0.1$ & 0.04 & 0.06 \\
\hline Urine $\mathrm{pH}^{9,10}$ & $8.2 \pm 0.1$ & $7.0 \pm 0.2$ & $6.5 \pm 0.1$ & $<0.01$ & 0.03 \\
\hline \multicolumn{6}{|l|}{ Postpartum } \\
\hline $\mathrm{DMI},{ }^{11} \mathrm{~kg} / \mathrm{d}$ & $18.1 \pm 0.9$ & $20.8 \pm 1.1$ & $19.6 \pm 0.9$ & 0.05 & 0.38 \\
\hline $\mathrm{DMI},{ }^{11} \%$ of BW & $2.6 \pm 0.2$ & $3.1 \pm 0.2$ & $2.9 \pm 0.2$ & 0.05 & 0.36 \\
\hline $\mathrm{EB}^{5,12} \mathrm{Mcal} / \mathrm{d}$ & $-9.5 \pm 1.7$ & $-6.4 \pm 1.9$ & $-6.0 \pm 1.6$ & 0.22 & 0.89 \\
\hline $\mathrm{EB},{ }^{6,12} \%$ Req. & $76.0 \pm 4.3$ & $86.0 \pm 5.1$ & $86.1 \pm 4.1$ & 0.13 & 0.99 \\
\hline $\mathrm{BW},{ }^{13} \mathrm{~kg}$ & $630.5 \pm 18.0$ & $618.9 \pm 21.3$ & $626.2 \pm 17.4$ & 0.67 & 0.79 \\
\hline $\mathrm{BCS}^{8,13}$ & $2.9 \pm<0.1$ & $2.8 \pm 0.1$ & $3.0 \pm<0.1$ & 0.07 & 0.04 \\
\hline BW loss, ${ }^{14} \mathrm{~kg}$ & $44.2 \pm 8.2$ & $43.9 \pm 10.0$ & $48.2 \pm 7.9$ & 0.98 & 0.74 \\
\hline BCS loss ${ }^{15}$ & $0.2 \pm 0.1$ & $0.3 \pm 0.1$ & $0.2 \pm 0.1$ & 0.18 & 0.45 \\
\hline
\end{tabular}

${ }^{1}$ Cows assigned to CON received a prepartum diet with a DCAD value of $12 \mathrm{mEq} / 100 \mathrm{~g}$ of DM; $21-\mathrm{ND}$ received a prepartum diet with a DCAD value of $-16 \mathrm{mEq} / 100 \mathrm{~g}$ of $\mathrm{DM}$ for $21 \mathrm{~d}$ prepartum; and those assigned to 42 ND received a prepartum diet with a DCAD value of $-16 \mathrm{mEq} / 100 \mathrm{~g}$ for $42 \mathrm{~d}$ prepartum.

${ }^{2} \mathrm{C} 1=\mathrm{CON}$ vs. $21-\mathrm{ND} ; \mathrm{C} 2=21-\mathrm{ND}$ vs. $42-\mathrm{ND}$

${ }^{3} \mathrm{DMI}=\mathrm{DMI}$ collected from $\mathrm{d}-42$ through 0 relative to calving.

${ }^{4} \mathrm{~EB}=$ energy balance calculated from $\mathrm{d}-42$ through 0 relative to calving.

${ }^{5} \mathrm{~EB}=$ energy intake - energy requirements.

${ }^{6} \mathrm{~EB}=$ energy intake/energy requirements (Req.) $\times 100$. Prepartum Req. $=\mathrm{NE}_{\mathrm{M}}+\mathrm{NE}_{\mathrm{P}}$ and postpartum Req. $=\mathrm{NE}_{\mathrm{M}}+\mathrm{NE}_{\mathrm{L}}$, where $\mathrm{NE}_{\mathrm{P}}=$ net energy requirements for pregnancy.

${ }^{7}$ Measured $\mathrm{d}-42$ through 0 relative to calving.

${ }^{8} \mathrm{BCS}=1-5$ scale, 0.25 unit increments.

${ }^{9}$ Sampled during wk $-5,-3,-2$, and -1 relative to calving.

${ }^{10}$ Mean for $21-N D$ during wk $-3,-2$, and -1 .

${ }^{11} \mathrm{DMI}=\mathrm{DMI}$ collected from d 0 through 28 relative to calving.

${ }^{12} \mathrm{~EB}=$ energy balance calculated from d 0 through 28 relative to calving.

${ }^{13}$ Measured d 0 through 28 relative to calving.

${ }^{14}$ Week $1 \mathrm{BW}$ - wk 4 BW.

${ }^{15}$ Week 1 BCS - wk 4 BCS.

\section{Milk Production and Components}

Milk production and components are reported in Table 6 and Figure 4. Daily milk production during the first $8 \mathrm{wk}$ of lactation averaged 39.2, 44.8, and 42.5 $\pm 2.1 \mathrm{~kg} / \mathrm{d}$ for CON, 21-ND, and 42-ND, respectively. Cows fed the anionic diet for $21 \mathrm{~d}$ prepartum had greater $(P=0.04)$ daily average milk yield compared with CON. No differences $(P=0.39)$ in milk production were measured between cows fed anionic diets for 21 or 42 d. Production data from wk 1 postpartum demonstrated anionic diets tended $(\mathrm{C} 1 ; P=0.06)$ to have faster starts in milk, yielding 31.3 and $28.5 \mathrm{~kg} / \mathrm{d}$ for 21-ND and 42-ND, respectively, in comparison with $26.7 \pm 1.8 \mathrm{~kg} / \mathrm{d}$ for CON (Table 6 ). Yield of $3.5 \% \mathrm{FCM}$ was similar among treatments and averaged 40.6, 43.6, and $41.5 \pm 2.6 \mathrm{~kg} / \mathrm{d}$ for CON, 21-ND, and $42-\mathrm{ND}$, respectively. Milk fat and protein yield $(\mathrm{kg} / \mathrm{d})$ did not differ among treatments, although 21-ND produced milk with a greater $(P=0.03)$ concentration of lactose compared with CON. Milk lactose yield was similar between $21-\mathrm{ND}$ and $42-\mathrm{ND}(P=0.35)$. Milk urea nitrogen concentrations were similar among treatments. Feed efficiency, expressed as kilograms of $3.5 \%$ FCM per kilograms of DMI, was unaffected by prepartum diets. Milk SCC was lower $(P=0.04)$ for $21-\mathrm{ND}$ compared with $\mathrm{CON}$; however, no difference $(P=0.47)$ was recorded between anionic treatments.

\section{Circulating Energy-Related Metabolites}

Prepartum serum NEFA concentrations were not different among treatments and averaged $206 \pm 24.6 \mu \mathrm{Eq} /$ L (Table 7). Prepartum NEFA concentrations for all treatments increased as calving approached, increasing from $107 \mu \mathrm{Eq} / \mathrm{L}$ at $\mathrm{d}-28$ to $334 \mu \mathrm{Eq} / \mathrm{L}$ at $\mathrm{d}-1$ before 
Table 5. Least squares means of DMI, energy balance, and milk yield from 1 wk prepartum through 1 wk postpartum from multiparous cows fed prepartum diets with positive DCAD (CON) for $42 \mathrm{~d}$ prepartum or negative DCAD (21-ND or $42-\mathrm{ND})$ for 21 or $42 \mathrm{~d}$ prepartum

\begin{tabular}{|c|c|c|c|c|c|}
\hline \multirow[b]{2}{*}{ Item } & \multicolumn{3}{|c|}{ Treatment $^{1}$} & \multicolumn{2}{|c|}{$P$-value ${ }^{2}$} \\
\hline & $\mathrm{CON}$ & $21-\mathrm{ND}$ & $42-\mathrm{ND}$ & $\mathrm{C} 1$ & $\mathrm{C} 2$ \\
\hline \multicolumn{6}{|l|}{$\mathrm{Wk}-1$} \\
\hline $\mathrm{DMI},{ }^{3} \mathrm{~kg} / \mathrm{d}$ & $13.2 \pm 0.9$ & $12.7 \pm 1.1$ & $11.3 \pm 0.9$ & 0.71 & 0.30 \\
\hline $\mathrm{DMI}^{3} \%$ of $\mathrm{BW}$ & $1.9 \pm 0.1$ & $1.8 \pm 0.2$ & $1.6 \pm 0.1$ & 0.76 & 0.34 \\
\hline $\mathrm{EB},{ }^{3,4} \mathrm{Mcal} / \mathrm{d}$ & $5.1 \pm 1.4$ & $3.5 \pm 1.7$ & $1.7 \pm 1.4$ & 0.48 & 0.39 \\
\hline \multicolumn{6}{|l|}{ Wk 1} \\
\hline $\mathrm{DMI}{ }^{5} \mathrm{~kg} / \mathrm{d}$ & $14.4 \pm 0.1$ & $16.1 \pm 1.1$ & $15.6 \pm 0.9$ & 0.23 & 0.69 \\
\hline $\mathrm{DMI},{ }^{5} \%$ of $\mathrm{BW}$ & $2.1 \pm 0.2$ & $2.4 \pm 0.2$ & $2.3 \pm 0.2$ & 0.25 & 0.63 \\
\hline $\mathrm{EB},{ }^{4,5} \mathrm{Mcal} / \mathrm{d}$ & $-11.8 \pm 2.2$ & $-9.1 \pm 2.3$ & $-8.0 \pm 1.8$ & 0.39 & 0.69 \\
\hline Milk, ${ }^{5} \mathrm{~kg} / \mathrm{d}$ & $26.7 \pm 1.6$ & $31.3 \pm 1.8$ & $28.5 \pm 1.5$ & 0.06 & 0.25 \\
\hline
\end{tabular}

${ }^{1}$ Cows assigned to CON received a prepartum diet with a DCAD value of $12 \mathrm{mEq} / 100 \mathrm{~g}$ of DM; $21-\mathrm{ND}$ received a prepartum diet with a DCAD value of $-16 \mathrm{mEq} / 100 \mathrm{~g}$ of DM for $21 \mathrm{~d}$ prepartum; and those assigned to 42 ND received a prepartum diet with a DCAD value of $-16 \mathrm{mEq} / 100 \mathrm{~g}$ for $42 \mathrm{~d}$ prepartum.

${ }^{2} \mathrm{C} 1=\mathrm{CON}$ vs. $21-\mathrm{ND} ; \mathrm{C} 2=21-\mathrm{ND}$ vs. $42-\mathrm{ND}$.

${ }^{3}$ Dry matter intake and energy balance from $\mathrm{d}-7$ through -1 relative to calving.

${ }^{4} \mathrm{~EB}=$ energy balance - energy requirements.

${ }^{5}$ Dry matter intake, energy balance, and milk yield from d 1 through 7 relative to calving.

calving (treatment $\times$ day; $P=0.56)$. Serum NEFA concentration peaked $7 \mathrm{~d}$ after calving $(644 \mu \mathrm{Eq} / \mathrm{L})$ and returned to precalving concentration by d 21 (402 $\mu \mathrm{Eq} / \mathrm{L})$. No treatment $\times$ day interaction was recorded for postpartum NEFA, as all treatments followed simi-

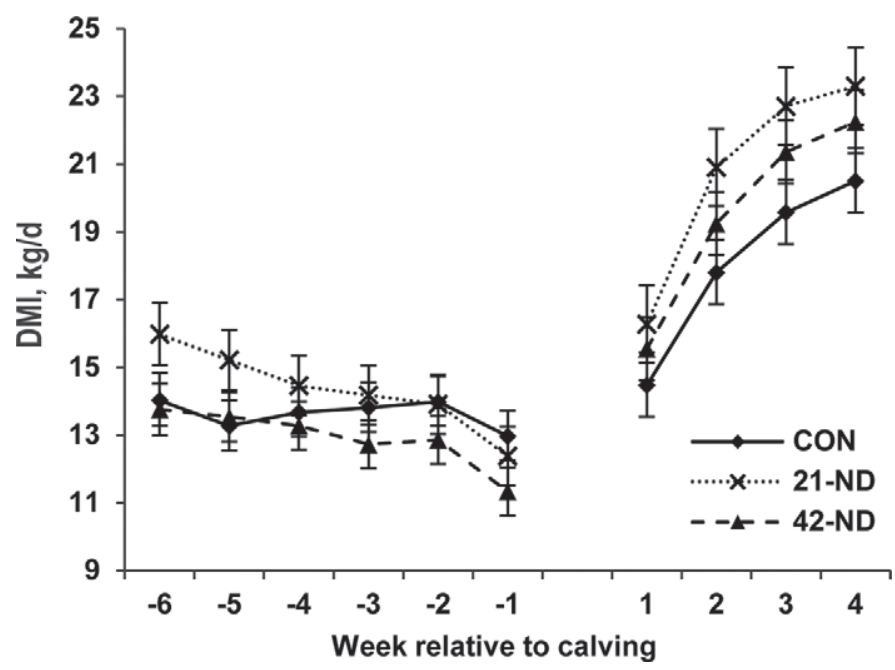

Figure 3. Temporal pattern of DMI from multiparous cows fed a control $(\mathrm{DCAD}=12 \mathrm{mEq} / 100 \mathrm{~g}$ of $\mathrm{DM})$ diet $(\mathrm{CON})$ for $42 \mathrm{~d}$ prepartum or negative DCAD (DCAD $=-16 \mathrm{mEq} / 100 \mathrm{~g}$ of $\mathrm{DM})$ diet for 21 or $42 \mathrm{~d}$ prepartum (21-ND or $42-\mathrm{ND})$. Values are LSM and error bars are SE; $\mathrm{n}=19,14$, and 20 for $\mathrm{CON}, 21-\mathrm{ND}$, and 42-ND, respectively. Prepartum DMI averaged 13.6, 14.4, and $12.9 \mathrm{~kg} / \mathrm{d}$ for CON, 21-ND, and $42-\mathrm{ND}$, respectively. Prepartum treatment contrasts resulted in $P$-values of 0.48 and 0.17 for CON vs. $21-\mathrm{ND}$ and $21-\mathrm{ND}$ vs. $42-\mathrm{ND}$ respectively. The $21-\mathrm{ND}$ cows tended $(P<0.10)$ to have greater DMI during wk -6 and -5 compared with $42-\mathrm{ND}$ and $\mathrm{CON}$, respectively. Postpartum DMI was higher $(P<0.05)$ for $21-\mathrm{ND}$ compared with CON. Postpartum DMI was similar between anionic treatments $(P$ $=0.38)$. lar trends over time. Serum BHBA concentrations on d 7 and 14 postpartum tended $(P \leq 0.10)$ to be lower for 21-ND compared with CON. Length of prepartum DCAD administration had no effect on BHBA concentrations on d 1 and 21 after calving. Similar concentrations of BHBA were reported for 42-ND compared with $21-\mathrm{ND}$ on $\mathrm{d} 7$ and 14 ( $P=0.71$ and 0.89 , respectively).

\section{Liver Composition}

Liver TL, TAG, and GLC content during the prepartum period was not affected by prepartum treatment (Table 7). Postpartum liver TL tended $(P=0.08)$ to be greater for CON compared with 21-ND (9.6 vs. 6.8 $\pm 1.2 \%)$ and $42-\mathrm{ND}$ was similar $(P=0.46)$ to $21-\mathrm{ND}$ (8.0 vs. $6.8 \pm 1.2 \%$; Figure 5). Postpartum liver TAG concentration tended to be greater $(P=0.09)$ in CON compared with 21-ND, but was similar between 21-ND and 42-ND. Liver TAG continued to increase (treatment $\times$ day; $P=0.08$ ) through $\mathrm{d} 7$ postpartum for CON, whereas 21-ND and 42-ND plateaued at $d 7$. Postpartum liver GLC concentrations were not different among treatments and averaged 2.2, 2.4, and $2.7 \pm$ $0.3 \%$ for CON, 21-ND, and 42-ND, respectively. Analysis of postpartum GLC concentration revealed a tendency $(P=0.10)$ for a treatment $\times$ day effect resulting from higher liver GLC on d 14 for 42-ND compared with CON and 21-ND.

\section{Cow Health and Calving Data}

Adverse health events (excluding udder edema) numbered 9,6 , and 5 for CON, 21-ND, and 42-ND, respec- 


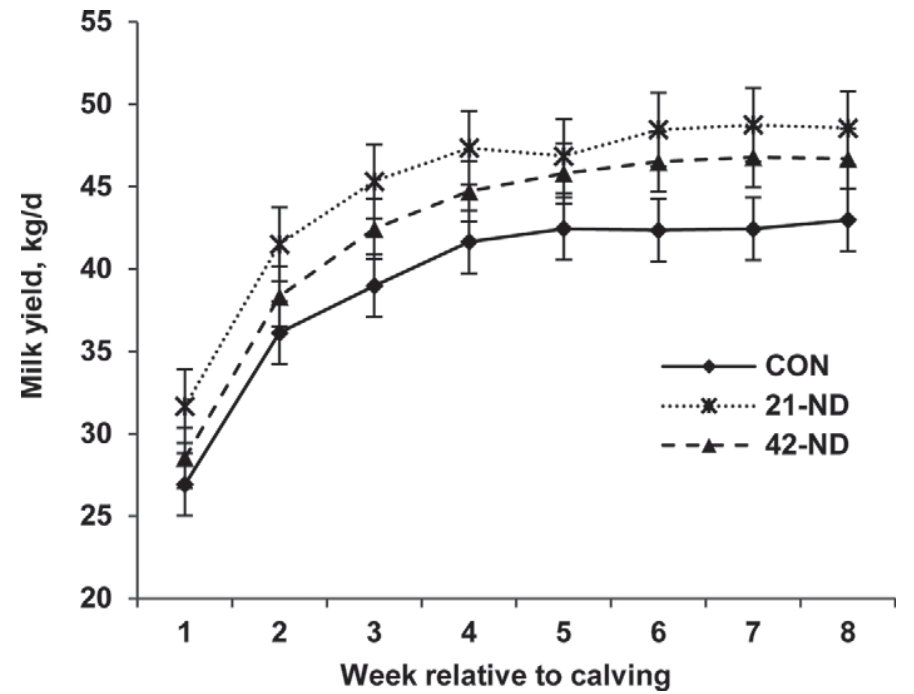

Figure 4. Milk yield through 56 DIM from multiparous cows fed a control (DCAD = $12 \mathrm{mEq} / 100 \mathrm{~g}$ of $\mathrm{DM}) \operatorname{diet}(\mathrm{CON})$ for $42 \mathrm{~d}$ prepartum or negative DCAD (DCAD $=-16 \mathrm{mEq} / 100 \mathrm{~g}$ of $\mathrm{DM})$ diet for 21 or $42 \mathrm{~d}$ prepartum (21-ND or $42-\mathrm{ND})$. Values are LSM and error bars are $\mathrm{SE} ; \mathrm{n}=19,14$, and 20 for CON, $21-\mathrm{ND}$, and $42-\mathrm{ND}$, respectively Milk yield averaged $39.2,44.8$, and $42.5 \mathrm{~kg} / \mathrm{d}$ for CON, 21-ND, and 42 -ND, respectively. Treatment contrasts resulted in $P$-values of 0.04 and 0.39 for CON vs. $21-\mathrm{ND}$ and $21-\mathrm{ND}$ vs. $42-\mathrm{ND}$, respectively.

tively (Table 8). Treatment means for colostrum yield, calf weight, and calving ease score were not affected by prepartum treatment (Table 9). Anionic supplementation did not affect colostrum yield. Colostrum immunoglobulin concentration was not measured.

\section{DISCUSSION}

\section{Urine $\mathrm{pH}$}

Urine $\mathrm{pH}$ values measured from cows fed negative DCAD prepartum treatments correlate to those reported (6.2-6.8) to be effective in the prevention of milk fever and hypocalcemia (Goff and Horst, 2003; Goff, 2008). Feeding the anionic diet in replacement of the control diet starting at wk -3 relative to parturition for 21-ND explains the difference reported for average urine $\mathrm{pH}$ when comparing 21-ND and 42-ND prepartum means. Upward drift of urine $\mathrm{pH}$ reported for $42-\mathrm{ND}$ cows is likely due to decreased DMI in the week before calving resulting in less anion intake. The urine $\mathrm{pH}$ difference recorded from 42-ND cows at wk -3 and -1 was not different $(P=0.15$; Figure 1$)$.

\section{Blood Ca}

Reasons for similar tCa between 21-ND and CON remain unclear, although greater milk production by 21-ND during 1 wk postpartum may be responsible for lower postpartum tCa. The tendency for greater tCa reported for 42-ND compared with 21-ND contradicts statements from Lean et al. (2006), who speculated the hypercalciuric effect of low-DCAD diets would be exacerbated if exposure to a negative DCAD prepartum diet was extended beyond $21 \mathrm{~d}$ prepartum, leaving lower amounts of available bone Ca for mobilization after parturition. Total Ca data reported from 42-ND also

Table 6. Least squares means from d 0 through 28 relative to calving from multiparous cows fed prepartum diets with positive DCAD (CON) for $42 \mathrm{~d}$ prepartum or negative DCAD (21-ND or 42-ND) for 21 or $42 \mathrm{~d}$ prepartum

\begin{tabular}{|c|c|c|c|c|c|}
\hline \multirow[b]{2}{*}{ Item } & \multicolumn{3}{|c|}{ Treatment $^{1}$} & \multicolumn{2}{|c|}{$P$-value ${ }^{2}$} \\
\hline & $\mathrm{CON}$ & $21-\mathrm{ND}$ & $42-\mathrm{ND}$ & $\mathrm{C} 1$ & $\mathrm{C} 2$ \\
\hline Milk, ${ }^{3} \mathrm{~kg} / \mathrm{d}$ & $39.2 \pm 1.7$ & $44.8 \pm 2.1$ & $42.5 \pm 1.7$ & 0.04 & 0.39 \\
\hline $3.5 \% \mathrm{FCM}^{4}{ }^{4} \mathrm{~kg} / \mathrm{d}$ & $40.6 \pm 2.2$ & $43.9 \pm 2.6$ & $41.5 \pm 2.1$ & 0.32 & 0.46 \\
\hline Milk fat, $\mathrm{kg} / \mathrm{d}$ & $1.5 \pm 0.1$ & $1.6 \pm 0.1$ & $1.5 \pm 0.1$ & 0.62 & 0.58 \\
\hline Milk protein, $\mathrm{kg} / \mathrm{d}$ & $1.2 \pm 0.1$ & $1.3 \pm 0.1$ & $1.3 \pm 0.1$ & 0.11 & 0.49 \\
\hline Milk lactose, $\mathrm{kg} / \mathrm{d}$ & $1.7 \pm 0.1$ & $2.0 \pm 0.1$ & $1.9 \pm 0.1$ & 0.03 & 0.35 \\
\hline MUN, mg/dL & $12.3 \pm 0.5$ & $13.2 \pm 0.5$ & $14.3 \pm 0.4$ & 0.21 & 0.11 \\
\hline Fat-to-protein ratio & $1.4 \pm 0.1$ & $1.2 \pm 0.1$ & $1.2 \pm 0.1$ & 0.12 & 0.90 \\
\hline Feed efficiency $^{5}$ & $2.4 \pm 0.1$ & $2.2 \pm 0.2$ & $2.2 \pm 0.1$ & 0.22 & 0.93 \\
\hline $\mathrm{SCC}^{6}$ & $238.6 \pm 48.9$ & $84.8 \pm 57.7$ & $139.3 \pm 47.2$ & 0.04 & 0.47 \\
\hline
\end{tabular}

${ }^{1}$ Cows assigned to CON received a prepartum diet with a DCAD value of $12 \mathrm{mEq} / 100 \mathrm{~g}$ of DM; $21-\mathrm{ND}$ received a prepartum diet with a DCAD value of $-16 \mathrm{mEq} / 100 \mathrm{~g}$ of DM for $21 \mathrm{~d}$ prepartum; and those assigned to 42 ND received a prepartum diet with a DCAD value of $-16 \mathrm{mEq} / 100 \mathrm{~g}$ for $42 \mathrm{~d}$ prepartum.

${ }^{2} \mathrm{C} 1=\mathrm{CON}$ vs. $21-\mathrm{ND} ; \mathrm{C} 2=21-\mathrm{ND}$ vs. $42-\mathrm{ND}$.

${ }^{3}$ Milk through d 56 postpartum.

${ }^{4} 3.5 \% \mathrm{FCM}=0.4324 \times(\mathrm{kg}$ of milk $)+16.2162 \times(\mathrm{kg}$ of fat $) ;$ through $\mathrm{d} 28$ postpartum.

${ }^{5} 3.5 \%$ FCM divided by DMI.

${ }^{6}$ Somatic cell count $\times 1,000$ cells $/ \mathrm{mL}$. 
Table 7. Least squares means of energy-related metabolites and liver lipid and carbohydrates from multiparous cows fed prepartum diets with positive DCAD (CON) for $42 \mathrm{~d}$ prepartum or negative DCAD (21-ND or 42$\mathrm{ND)}$ for 21 or $42 \mathrm{~d}$ prepartum

\begin{tabular}{|c|c|c|c|c|c|}
\hline \multirow[b]{2}{*}{ Item } & \multicolumn{3}{|c|}{ Treatment $^{1}$} & \multicolumn{2}{|c|}{$P$-value ${ }^{2}$} \\
\hline & $\mathrm{CON}$ & $21-\mathrm{ND}$ & $42-\mathrm{ND}$ & $\mathrm{C} 1$ & $\mathrm{C} 2$ \\
\hline \multicolumn{6}{|l|}{ Prepartum } \\
\hline $\mathrm{NEFA}^{3}{ }^{3} \mu \mathrm{Eq} / \mathrm{L}$ & $219.4 \pm 20.6$ & $186.2 \pm 24.6$ & $212.7 \pm 20.2$ & 0.30 & 0.41 \\
\hline Glycogen ${ }^{4} \%$ & $5.4 \pm 0.5$ & $5.2 \pm 0.6$ & $5.9 \pm 0.5$ & 0.78 & 0.39 \\
\hline Total lipid, ${ }^{4} \%$ & $4.3 \pm 0.2$ & $4.5 \pm 0.2$ & $4.7 \pm 0.2$ & 0.55 & 0.37 \\
\hline Triacylglycerol, ${ }^{5} \%$ & $0.6 \pm 0.1$ & $0.5 \pm 0.1$ & $0.4 \pm 0.1$ & 0.51 & 0.54 \\
\hline \multicolumn{6}{|l|}{ Postpartum } \\
\hline $\mathrm{NEFA}^{6}{ }^{6} \mu \mathrm{Eq} / \mathrm{L}$ & $590.9 \pm 62.9$ & $470.0 \pm 73.8$ & $557.3 \pm 60.0$ & 0.21 & 0.36 \\
\hline Glycogen, ${ }^{7} \%$ & $2.2 \pm 0.3$ & $2.4 \pm 0.3$ & $2.7 \pm 0.3$ & 0.59 & 0.52 \\
\hline Total lipid, ${ }^{7} \%$ & $9.6 \pm 1.0$ & $6.8 \pm 1.2$ & $8.0 \pm 1.0$ & 0.08 & 0.46 \\
\hline Triacylglycerol, ${ }^{8} \%$ & $5.2 \pm 0.7$ & $3.3 \pm 0.8$ & $4.0 \pm 0.7$ & 0.09 & 0.53 \\
\hline \multicolumn{6}{|l|}{$\mathrm{BHBA},{ }^{9} \mathrm{mg} / \mathrm{dL}$} \\
\hline d 1 & $0.9 \pm 0.1$ & $1.0 \pm 0.1$ & $1.1 \pm 0.1$ & 0.95 & 0.22 \\
\hline d 7 & $1.4 \pm 0.3$ & $0.8 \pm 0.3$ & $1.0 \pm 0.3$ & 0.10 & 0.71 \\
\hline d 14 & $1.5 \pm 0.3$ & $0.8 \pm 0.3$ & $0.8 \pm 0.3$ & 0.08 & 0.89 \\
\hline d 21 & $1.4 \pm 0.3$ & $0.8 \pm 0.3$ & $1.1 \pm 0.3$ & 0.21 & 0.56 \\
\hline
\end{tabular}

${ }^{1}$ Cows assigned to CON received a prepartum diet with a DCAD value of $12 \mathrm{mEq} / 100 \mathrm{~g}$ of DM; $21-\mathrm{ND}$ received a prepartum diet with a DCAD value of $-16 \mathrm{mEq} / 100 \mathrm{~g}$ of $\mathrm{DM}$ for $21 \mathrm{~d}$ prepartum; and those assigned to 42 ND received a prepartum diet with a DCAD value of $-16 \mathrm{mEq} / 100 \mathrm{~g}$ for $42 \mathrm{~d}$ prepartum.

${ }^{2} \mathrm{C} 1=\mathrm{CON}$ vs. $21-\mathrm{ND} ; \mathrm{C} 2=21-\mathrm{ND}$ vs. $42-\mathrm{ND}$.

${ }^{3}$ Nonesterified fatty acid analysis of serum from $\mathrm{d}-28,-21,-14,-7,-3$, and -1 relative to calving.

${ }^{4}$ Percent of total lipids from $\mathrm{d}-14$ relative to calving.

${ }^{5}$ Percent of wet weight from liver samples from $d-14$ relative to calving.

${ }^{6}$ Nonesterified fatty acid analysis of serum from d 1, 7, 14, and 21 relative to calving.

${ }^{7}$ Percent of total lipids from d 7 and 14 relative to calving.

${ }^{8}$ Percent of wet weight from liver samples from d 7 and 14 relative to calving.

${ }^{9}$ Beta-hydroxybutyrate analysis of serum from d 1, 7, 14, and 21 relative to calving.

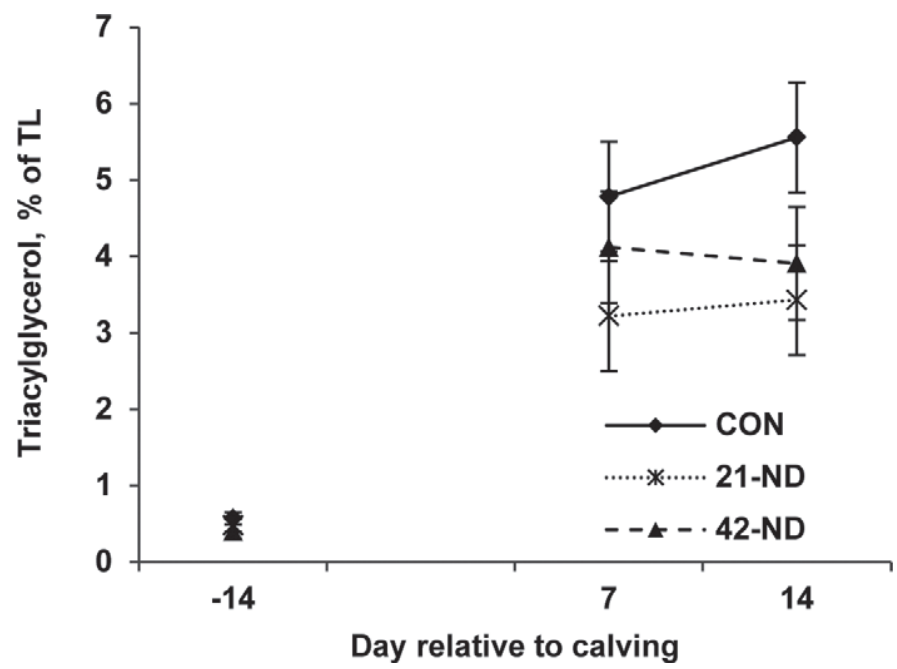

Figure 5. Liver triacylglycerol from multiparous cows fed a control $(\mathrm{DCAD}=12 \mathrm{mEq} / 100 \mathrm{~g}$ of $\mathrm{DM}) \operatorname{diet}(\mathrm{CON})$ for $42 \mathrm{~d}$ prepartum or negative DCAD (DCAD $=-16 \mathrm{mEq} / 100 \mathrm{~g}$ of $\mathrm{DM})$ diet for 21 or 42 $\mathrm{d}$ prepartum (21-ND or 42-ND). Values are LSM and error bars are $\mathrm{SE} ; \mathrm{n}=19,14$, and 20 for CON, 21-ND, and 42-ND, respectively. Postpartum liver triacylglycerol averaged 5.2, 3.3, and $4.0 \%$ of total lipids for CON, 21-ND, and 42-ND, respectively. Treatment contrasts resulted in $P$-values of 0.09 and 0.53 for CON vs. 21-ND and 21-ND vs. $42-\mathrm{ND}$, respectively. Postpartum treatment $\times$ day effect $=P=$ 0.08 .
Table 8. Health events recorded d -42 prepartum through d 56 postpartum from multiparous cows fed prepartum diets with positive DCAD (CON) for $42 \mathrm{~d}$ prepartum or negative DCAD (21-ND or 42ND) for 21 or $42 \mathrm{~d}$ prepartum

\begin{tabular}{lccc}
\hline & \multicolumn{3}{c}{ Treatment $^{1}$} \\
\cline { 2 - 4 } Item & CON & 21-ND & $42-\mathrm{ND}$ \\
\hline Displaced abomasum $_{\text {Dystocia }}{ }^{2}$ & 1 & 0 & 0 \\
Ketosis & 0 & 2 & 2 \\
Mastitis & 1 & 0 & 0 \\
Metritis & 1 & 0 & 0 \\
Milk fever $^{3}$ & 2 & 1 & 0 \\
Retained placenta $^{5}$ & 0 & 0 & $1^{4}$ \\
Twins $_{\text {Udder edema }}{ }^{6}$ & 3 & 1 & 1 \\
& 1 & 2 & 1 \\
\hline
\end{tabular}

${ }^{1}$ Cows assigned to CON received a prepartum diet with a DCAD value of $12 \mathrm{mEq} / 100 \mathrm{~g}$ of $\mathrm{DM} ; 21-\mathrm{ND}$ received a prepartum diet with a DCAD value of $-16 \mathrm{mEq} / 100 \mathrm{~g}$ of $\mathrm{DM}$ for $21 \mathrm{~d}$ prepartum; and those assigned to $42-\mathrm{ND}$ received a prepartum diet with a DCAD value of $-16 \mathrm{mEq} / 100 \mathrm{~g}$ for $42 \mathrm{~d}$ prepartum.

${ }^{2}$ Dystocia was scored on a 1 to 5 scale $(1=$ easy, $5=$ mechanically assisted pull); score of 4 or higher recorded.

${ }^{3}$ Diagnosed by recumbency.

${ }^{4}$ Experienced milk fever in previous lactation.

${ }^{5}$ Placenta retained more than $24 \mathrm{~h}$.

${ }^{6}$ No severity scale used. 
Table 9. Least squares means of colostrum yield, calf weight, and calving ease data from multiparous cows fed prepartum diets with a positive DCAD $(\mathrm{CON})$ for $42 \mathrm{~d}$ prepartum or negative DCAD (21-ND or 42-ND) for 21 or $42 \mathrm{~d}$ prepartum

\begin{tabular}{|c|c|c|c|c|c|}
\hline \multirow[b]{2}{*}{ Item } & \multicolumn{3}{|c|}{ Treatment $^{1}$} & \multicolumn{2}{|c|}{$P$-value ${ }^{2}$} \\
\hline & $\mathrm{CON}$ & $21-\mathrm{ND}$ & $42-\mathrm{ND}$ & $\mathrm{C} 1$ & $\mathrm{C} 2$ \\
\hline Colostrum, ${ }^{3} \mathrm{~kg}$ & $6.4 \pm 0.7$ & $6.1 \pm 0.9$ & $6.8 \pm 0.7$ & 0.80 & 0.59 \\
\hline Calf weight, $\mathrm{kg}$ & $44.6 \pm 2.0$ & $41.1 \pm 2.5$ & $43.5 \pm 1.8$ & 0.28 & 0.44 \\
\hline Calving ease ${ }^{4}$ & $1.7 \pm 0.3$ & $1.6 \pm 0.4$ & $1.7 \pm 0.3$ & 0.83 & 0.77 \\
\hline
\end{tabular}

${ }^{1}$ Cows assigned to CON received a prepartum diet with a DCAD value of $12 \mathrm{mEq} / 100 \mathrm{~g}$ of DM; 21-ND received a prepartum diet with a DCAD value of $-16 \mathrm{mEq} / 100 \mathrm{~g}$ of $\mathrm{DM}$ for $21 \mathrm{~d}$ prepartum and those assigned to 42 ND received a prepartum diet with a DCAD value of $-16 \mathrm{mEq} / 100 \mathrm{~g}$ for $42 \mathrm{~d}$ prepartum.

${ }^{2} \mathrm{C} 1=\mathrm{CON}$ vs. $21-\mathrm{ND} ; \mathrm{C} 2=21-\mathrm{ND}$ vs. $42-\mathrm{ND}$

${ }^{3}$ First milk weight.

${ }^{4}$ Calving ease scored on a 1 to 5 scale $(1=$ unassisted, $5=$ mechanically assisted pull).

disagree with predictive models calculated by DeGaris et al. (2010), which expected no change in postpartum tCa concentration in cows fed negative DCAD diets for varying amounts of time. Increased tCa through extending duration of negative DCAD feeding can be supported by data from Block (1984), who reported increased tCa from cows receiving anionic diets for $45 \mathrm{~d}$ prepartum in comparison with positive DCAD-fed control cows. Benefits of increased tCa seen in this study are hard to confirm due to lack of a response seen in iCa from cows fed anionic diets. Low intensity of blood sampling for iCa (d 1 and 7) may explain the lack of treatment differences in postpartum iCa. Additionally, dietary factors contributing to lack of responses in postpartum blood Ca may be related to the minimal difference in DCAD resulting from high inclusion of low-cation forages. Ramos-Nieves et al. (2009) supplemented anions to a low-cation prepartum diet (DCAD $=-15 \mathrm{mEq} / 100 \mathrm{~g}$ of $\mathrm{DM})$ and reported no differences in postpartum plasma $\mathrm{Ca}$ concentrations in comparison with a low-cation control diet $(\mathrm{DCAD}=11 \mathrm{mEq} / 100$ $\mathrm{g}$ of DM). Siciliano-Jones et al. (2008) reported greater plasma $\mathrm{Ca}$ concentrations when supplementing anions to a low-cation prepartum diet $(\mathrm{DCAD}=-10$ $\mathrm{mEq} / 100 \mathrm{~g}$ of DM) compared with a low-cation control $\operatorname{diet}(\mathrm{DCAD}=6 \mathrm{mEq} / 100 \mathrm{~g}$ of $\mathrm{DM})$. Inconsistencies in effects of negative DCAD fed in low-cation prepartum diets on postpartum Ca homeostasis warrants reevaluation of this feeding strategy.

\section{$D M I$ and $E B$}

Others supplying anions during the dry period in high-forage, moderate-energy diets have reported mixed effects on prepartum DMI (Siciliano-Jones et al., 2008; Ramos-Nieves et al., 2009). Siciliano-Jones et al. (2008) reported no differences in prepartum DMI comparing cows receiving an anionic or cationic diet; however, a significant reduction $(1.2 \mathrm{~kg} / \mathrm{d})$ was reported by Ramos-Nieves et al. (2009) when feeding a similar prepartum diet. In both studies anionic diets were fed $21 \mathrm{~d}$ prepartum. No data are available for comparing effects of feeding negative DCAD in high-forage, low-cation diets for $<21$ d. Data from Block (1984) reports that cows can be fed negative DCAD diets for extended periods without having detrimental effects of prepartum DMI; however, significant differences are apparent in the method of anion supplementation and diet nutrient profile of the prepartum diet used in that trial.

Prior to the beginning of the trial, cows were allocated to treatments to ensure equal DMI among treatments at dry-off, although an approximately $2.0 \mathrm{~kg} / \mathrm{d}$ difference in prepartum DMI was recorded for 21-ND compared with 42-ND and CON during wk -6 and -5 . Dry matter intake was similar among treatments for wk -4 through calving. Prepartum EB was similar among treatments which is consistent with others feeding similar prepartum diets (Ramos-Nieves et al., 2009).

Expectations of greater DMI from anionic-fed cows in the first week postpartum due to increased tCa were not met. Postpartum DMI was similar for 21-ND compared with CON and 42-ND during wk 1 postpartum; however, significant differences were reported when analyzing the 8-wk postpartum period. These data are inconsistent with results reported by others (Siciliano-Jones et al., 2008; Ramos-Nieves et al., 2009) feeding similar high-forage, low-cation diets for $21 \mathrm{~d}$ before calving. Postpartum DMI was similar between cows receiving prepartum anionic diets for 21 or 42 d prepartum. Reasons for increased postpartum DMI recorded for 21-ND may be best described by the prepartum differences in DMI, or through carryover effects of improved ruminal function due to inclusion of Biochlor (Church \& Dwight Co. Inc.; Lean et al., 2005) in the prepartum diet. Increased tCa reported for 42-ND compared with 21-ND may be responsible for reducing 
the postpartum difference in DMI between these treatments and causing numerically higher postpartum DMI when comparing 42-ND with CON.

Postpartum EB was least negative for cows receiving the anionic diet for $42 \mathrm{~d}$ prepartum. Decreases in postpartum BCS have been reported (Ramos-Nieves et al., 2009) for cows fed negative DCAD prepartum diets similar to the diets fed during this trial. Body weight loss was similar among treatments, which suggests prepartum diet did not affect postpartum BCS. Others feeding high-forage, low-DCAD diets reported no effects on postpartum BCS even though milk production was increased in the low DCAD treatment (SicilianoJones et al., 2008); postpartum DMI and EB data were not reported in that study.

\section{Milk Production and Components}

Several studies have reported increased milk production (Block, 1984; Siciliano-Jones et al., 2008; DeGroot et al., 2010) following anionic supplementation during the prepartum period. In the current study, milk production was increased by supplementing anions $21 \mathrm{~d}$ before calving, which is consistent with data reported by others feeding similar prepartum diets during a traditional 21-d period (Siciliano-Jones et al., 2008). Milk production by $42-\mathrm{ND}$ was similar to milk production from 21-ND. Block (1984) and DeGroot et al. (2010) reported increased milk yield after supplying anions for 45 and $28 \mathrm{~d}$ before calving, respectively, suggesting anionic supplementation periods $>21 \mathrm{~d}$ may be more conducive to milk production responses. Similar to DeGroot et al. (2010), our study measured no tCa differences between anionic treatments producing greater milk and positive DCAD-fed controls, suggesting the addition of BioChlor (Church \& Dwight Co. Inc.) as the anion source in both studies may have been responsible for increasing production through alterations in ruminal function described through in vitro work by Lean et al. (2005). Supplementing BioChlor or Fermenten (Church \& Dwight Co. Inc.) to continuous rumen culture fermenters resulted in a $15.7 \%$ increase in microbial nitrogen, a $37 \%$ increase in ruminal protein digestion, and a $25 \%$ increase in fermenter ammonia nitrogen concentrations (Lean et al., 2005). The use of a similar product, SoyChlor (West Central, Ralston, IA), has also been used as the anion source by others reporting milk yield responses after anionic prepartum diets (Siciliano-Jones et al., 2008).

Research by DeGroot et al. (2010) and the current trial support the hypothesis that carryover effects of BioChlor (Church \& Dwight Co. Inc.) inclusion in the prepartum diet may have influenced postpartum production. In the current study, the comparison between anion sources was not made; however, DeGroot et al. (2010) reported increased milk production by cows receiving anions from BioChlor rather than anionic salts. A milk protein yield response reported by SicilianoJones et al. (2008) agrees with data reported in this trial. DeGroot et al. (2010) also reported a 5\% increase in milk protein yield when feeding BioChlor during the prepartum period, although this difference was not significant. Siciliano-Jones et al. (2008) reported greater milk solids yield from multiparous cows receiving similar prepartum diets, only milk protein and fat were reported, however.

\section{Lipid Metabolism}

Feeding or management strategies that reduce BHBA concentration in the first weeks of lactation (d 7-14 postpartum) results in greater milk production (Duffield et al., 2009), reduced incidence of metabolic disorders (Chapinal et al., 2011), and increased reproductive efficiency (Chapinal et al., 2012). Concentrations of BHBA were lower $(P<0.10)$ in $21-N D$ compared with CON on d 7 and d 14 postpartum, and were similar between 21-ND and 42-ND. These data suggest that increased DMI reported for 21-ND and 42-ND was sufficient to cause a reduction in reliance on mobilization of body adipose stores, which is supported by lower liver TL and TAG reported for 21-ND and 42-ND. Elevated postpartum liver TAG has been associated with decreased gluconeogenic capacities (Grummer, 1993), which may be the reason for reduced liver glycogen in $\mathrm{CON}$. These data are also supported by greater lactose concentrations in milk from anionic fed cows, as glucose is a precursor for lactose synthesis. The treatment $\times$ day effects $(P=0.08)$ for liver TL and TAG suggest cows fed anionic treatments decreased utilization and reliance on body adipose stores sooner into lactation compared with CON.

\section{CONCLUSIONS}

Results of our study agree with evidence that anionic supplementation for $21 \mathrm{~d}$ prepartum provides benefits on postpartum performance compared with feeding positive DCAD prepartum diets. Additionally, $42 \mathrm{~d}$ of negative DCAD feeding did not have detrimental effects on postpartum performance in multiparous dairy cows and may provide similar or increased postpartum protection against hypocalcemia and metabolic disorders compared with $21 \mathrm{~d}$ of negative DCAD feeding strategies. Practical applications of this research indicate the acceptability of grouping cohorts of cows together and feeding a negative DCAD diet for the entirety of a $42 \mathrm{~d}$ dry period. Limitations of this research include (1) the 
use of only multiparous cows, (2) effectiveness of the feeding strategy was not evaluated in a freestall setting, and (3) comparisons were not made on the effects of anion source during extended negative DCAD feeding. Future research with a greater number of experimental units should be conducted before clear recommendations for extended feeding of negative DCAD can be made.

\section{ACKNOWLEDGMENTS}

This study was supported in part by funds from the State of Minnesota appropriated to the Minnesota Agricultural Experiment Station (St. Paul) and Church and Dwight Co. Inc.

\section{REFERENCES}

AOAC International. 1995. Official Methods of Analysis. 16th ed. AOAC International, Arlington, VA.

Block, E. 1984. Manipulating dietary anions and cations for prepartum dairy cows to reduce incidence of milk fever. J. Dairy Sci. 67:2939-2948

Chapinal, N., M. Carson, T. F. Duffield, M. Capel, S. Godden, M. W. Overton, J. E. P. Santos, and S. J. LeBlanc. 2011. The association of serum metabolites with clinical disease during the transition period. J. Dairy Sci. 94:4897-4903.

Chapinal, N., M. Carson, S. J. LeBlanc, K. E. Leslie, S. Godden, M. Capel, J. E. P. Santos, M. W. Overton, and T. F. Duffield. 2012. The association of serum metabolites in the transition period with milk production and early-lactation reproductive performance. J. Dairy Sci. 95:1301-1309.

DeGaris, P. J., and I. J. Lean. 2008. Milk fever in dairy cows: A review of pathophysiology and control principles. Vet. J. 176:58-69.

DeGaris, P. J., I. J. Lean, A. R. Rabiee, and M. A. Stevenson. 2010. Effects of increasing days of exposure to prepartum diets on the concentration of certain blood metabolites in dairy cows. Aust. Vet. J. 88:137-145.

DeGroot, M. A., E. Block, and P. D. French. 2010. Effect of prepartum anionic supplementation on periparturient feed intake, health, and milk production. J. Dairy Sci. 93:5268-5279.

Duffield, T. F., K. D. Lissemore, B. W. McBride, and K. E. Leslie. 2009. Impact of hyperketonemia in early lactation dairy cows on health and production. J. Dairy Sci. 92:571-580.

Ferguson, J. D., D. T. Galligan, and N. Thomsen. 1994. Principal descriptors of body condition score in Holstein cows. J. Dairy Sci. $77: 2695-2703$

Fletcher, M. J. 1968. A colorimetric method for estimating serum triglycerides. Clin. Chim. Acta 22:393-397.

Foster, L. B., and R. T. Dunn. 1973. Stable reagents for determination of serum triglycerides by a colorimetric Hantzsch condensation method. Clin. Chem. 19:338-340.

Gaynor, P. J., F. J. Mueller, J. K. Miller, N. Ramsey, J. P. Goff, and R. L. Horst. 1989. Parturient hypocalcemia in Jersey cows fed alfalfa haylage-based diets with different cation to anion ratios. J. Dairy Sci. 72:2525-2531.

Goff, J. P. 2008. The monitoring, prevention, and treatment of milk fever and subclinical hypocalcemia in dairy cows. Vet. J. 176:50-57.

Goff, J. P., and R. L. Horst. 2003. Role of acid-base physiology on the pathogenesis of parturient hypocalcemia (milk fever)-The DCAD theory in principal and practice. Acta Vet. Scand. Suppl. 97:51-56

Grummer, R. R. 1993. Etiology of lipid-related metabolic disorders in periparturient dairy cows. J. Dairy Sci. 76:3882-3896
Hara, A., and N. S. Radin. 1978. Lipid extraction of tissues with a low-toxicity solvent. Anal. Biochem. 90:420-426.

Hasegawa, N., A. Nishiwaki, K. Sugawara, and I. Ito. 1997. The effects of social exchange between two groups of lactating primiparous heifers on milk production, dominance order, behavior and adrenocortical response. Appl. Anim. Behav. Sci. 51:15-27.

Hughes, J. P. 1962. A simplified instrument for obtaining liver biopsies in cattle. Am. J. Vet. Res. 23:1111-1113.

Joyce, P. W., W. K. Sanchez, and J. P. Goff. 1997. Effect of anionic salts in prepartum diets based on alfalfa. J. Dairy Sci. 80:28662875 .

Lean, I. J., P. J. DeGaris, D. M. McNeil, and E. Block. 2006. Hypocalcemia in dairy cows: Meta-analysis and dietary cation anion difference theory revisited. J. Dairy Sci. 89:669-684.

Lean, I. J., T. K. Miller Webster, W. Hoover, W. Chalupa, C. J. Sniffen, E. Evans, E. Block, and A. R. Rabiee. 2005. Effects of Biochlor and Fermenten on microbial protein synthesis in continuous culture fermenters. J. Dairy Sci. 88:2524-2536.

Leclerc, H., and E. Block. 1989. Effects of reducing dietary cationanion balance for prepartum dairy cows with specific reference to hypocalcemic parturient paresis. Can. J. Anim. Sci. 69:411-423.

Littell, R. C., G. A. Milliken, W. W. Stroup, and R. D. Wolfinger 1996. SAS System of Mixed Models. SAS Institute Inc., Cary, NC.

Lo, S., J. C. Russell, and A. W. Taylor. 1970. Determination of glycogen in small tissue samples. J. Appl. Physiol. 28:234-236.

Moore, S. J., M. J. VandeHaar, B. K. Sharma, T. E. Pilbeam, D K. Beede, H. F. Bucholtz, J. S. Liesman, R. L. Horst, and J. P. Goff. 2000. Effects of altering dietary cation-anion difference on calcium and energy metabolism in peripartum cows. J. Dairy Sci 83:2095-2104

National Animal Health Monitoring System (NAHMS). 2007. Part I: Reference of Dairy Cattle Health and Management Practices in the United States. USDA-Animal and Plant Health Inspection Service Veterinary Services, Ft. Collins, CO

National Research Council. 2001. Nutrient Requirements of Dairy Cattle. 7th Rev. Ed. Natl. Acad. Press, Washington, DC.

Nordlund, K. 2009. The five key factors in transition cow management of freestall dairy herds. Pages 27-32 in Proc. 46th Florida Dairy Prod. Conf., Gainesville, FL.

Oetzel, G. R., and J. A. Barmore. 1993. Intake of a concentrate mixture containing various anionic salts fed to pregnant, nonlactating dairy cows. J. Dairy Sci. 76:1617-1623.

Oetzel, G. R., J. D. Olson, C. R. Curtis, and M. J. Fettman. 1988 Ammonium chloride and ammonium sulfate for prevention of parturient paresis in dairy cows. J. Dairy Sci. 71:3302-3309.

Ramos-Nieves, J. M., B. J. Thering, M. R. Waldron, P. W. Jardon, and T. R. Overton. 2009. Effects of anion supplementation to lowpotassium prepartum diets on macromineral status and performance of periparturient dairy cows. J. Dairy Sci. 92:5677-5691.

Reinhardt, T. A., J. D. Lippolis, B. J. McCluskey, J. P. Goff, and R. L. Horst. 2011. Prevalence of subclinical hypocalcemia in dairy herds. Vet. J. $188: 122-124$

SAS Institute. 1999. SAS User's Guide: Statistics. Version 9.2 ed. SAS Inst. Inc., Cary, NC.

Siciliano-Jones, J., P. W. Jardon, M. Kucerak, and M. B. de Ondarza. 2008. Case study: Early lactation production, body condition, and incidence of disease in Holstein cows fed a low-potassium diet alone or supplemented with chloride prepartum. Prof. Anim. Sci. 24:661-667.

Vagnoni, D. B., and G. R. Oetzel. 1998. Effects of dietary cationanion difference on the acid-base status of dry cows. J. Dairy Sci 81:1643-1652.

Veenhuizen, J. J., J. K. Drackley, M. J. Richards, T. P. Sanderson, L. D. Miller, and J. W. Young. 1991. Metabolic changes in blood and liver during development and early treatment of experimental fatty liver and ketosis in cows. J. Dairy Sci. 74:4238-4253.

von Keyserlingk, M. A., D. Olenick, and D. Weary. 2008. Acute behavioral effects of regrouping dairy cows. J. Dairy Sci. 91:1011-1016. 